\title{
KEKUATAN DRAMATURGI DIBANDING KEPEMIMPINAN DALAM MEMPENGARUHI KINERJA KARYAWAN AMIK CITRA BUANA INDONESIA SUKABUMI
}

\author{
Rafdi $^{1}$, Roefaidah Harijati ${ }^{2}$ \\ 1,2Akademi Pariwisata CBI Sukabumi \\ ${ }^{1}$ rafdi@gmail.com \\ ${ }^{2}$ Roefaidah @ gmail.com
}

\begin{abstract}
Abstrak - Penelitian ini bertujuan untuk mengetahui sejauh mana pengaruh Dramaturgi terhadap Kinerja melampaui Pengaruh kepemimpinan terhadap Kinerja. Untuk itu perlu terlebih dahulu mengetahui sejauh mana pengaruh Dramaturgi terhadap Kinerja, sejauh mana pengaruh Kepemimpinan terhadap Kinerja, sejauh mana pengaruh Dramaturgi dan Kepemimpinan sekaligus terhadap Kinerja, sejauh mana faktor lain ( epselon ) yang mempengaruhi kinerja. Penelitian ini dilakukan terhadap karyawan AMIK CBI Sukabumi. Jumlah sampel yang dijadikan responden sebanyak lima puluh responden dari sebanyak delapan puluh delapan populasi. Konteks kepemimpinan dalam penelitian ini mengacu ke pada pemahaman cara memimpin oleh pimpinan yakni BPH dan Direktur ke pada Karyawan. Adapun pemahaman Dramaturgi mengacu ke pada pemahaman Impression Management oleh BPH dan Direktur dalam bentuk interaksi sosial dengan Karyawan pada suasana sosial tertentu dengan kecenderungan situasional yang dibagi ke dalam dua situasional, yaitu interaksi sosial di pentas belakang (back stage ) dan di pentas depan (front stage ). Metode penelitian menggunakan desain aksplanasi, menguji pengaruh antar tiga variabel, variabel $\mathrm{X} 1, \mathrm{X} 2, \mathrm{Y}$ berdasarkan analisis kuantitatif melalui olah data SPSS . Hasil pengolahan data menunjukkan pengaruh Dramaturgi terhadap Kinerja jauh lebih tinggi dibanding pengaruh kepemimpinan terhadap kinerja, pengaruh Dramaturgi terhadap kinerja positif dan signifikan, pengaruh kepemimpinan terhadap kinerja positif namun tidak signifikan, pengaruh Dramaturgi dan Kepemimpinan sekaligus positif dan signifikan. Factor lain (epsilon) yang mempengaruh kinerja sebesar tujuh puluh delapan koma tiga persen. Ditemukan hal menarik pada penelitian ini melalui pengaruh Dramaturgi dengan jabaran unsur unsurnya yang posistif dan signifikan terhadap Kinerja hingga sudah saatnya menganalisis faktor faktor situasional melalui kekuatan manajemen kesan/impression management oleh pimpinan terhadap karyawan pada saat interaksi sosial sebagai salah satu dimensi sangat penting yang mempengaruhi Kinerja Karyawan . Unsur unsur tersebut meliputi kekuatan pimpinan melalui situasi : dengan gestural, perangkat peran, penonjolan, takaran waktu interaksi, teknik komunikasi dengan lembut, dan unsur Dramaturgi lain nya .
\end{abstract}

Kata kunci : Kekuatan Dramaturgi pimpinan mempengaruhi kinerja karyawan.

Abstract - This study aims to determine the extent to which the influence of drama on performance exceeds the influence of leadership on performance. for that it is necessary in advance to know the extentof the influence of Dramaturgy on Performance, the extent of the influence of Leadership on Performance, the extent of the influence of Dramaturgy and Leadership at the same time on

performance, the extent to which other factors (epchelon) influence performance. This research was conducted on the employees of AMIK CBI Sukabumi.The number of samples used as respondents was fifty respondents from a total of eighty eight populations. The leadership context in this study refers to the understanding of how to lead by the leadership, namely BPH and the Director to the employees. As for the understanding of Dramaturgy refers to the understanding of Impression Management by BPH and the Director in the form of social interaction with employeesin certain social situations with situational tendencies which are divided into two situational, namely social interaction on the back stage) and on the front stage.The research method used was an explanation design, testing the effect between three variables, variables X1, X2, Y based on quantitative analysis through SPSS data processing. The results of data 
processing show that the influence of Dramaturgy on performance is much higher than the influence of leadership on performance, the influence of Dramaturgy on performance is positive and significant, the influence of leadership on performance is positive but not significant, the influence of Dramaturgy andLeadership is at the same time positive and significant.another factor (epsilon) that affects the performance of seventy-eight point three percent.It was found interesting in this study through the influence of Dramaturgy with a description of its positive and significant elements of performance that it is time to analyze situational factors through the power of impression management by leaders on employees atwhen social interaction is a very important dimension that affects employee performance. .These elements include the power of leadership through situations: with gestures, role devices, prominence, measure of interaction time, gentle communication techniques and other elements of Dramaturgy.

Keywords : The Dramaturgi strength of Leader influences the employes 'performance

\section{PENDAHULUAN}

Permasalahan kinerja merupakan salah satu masalah pokok yang dihadapi setiap organisasi. Sebagaimana telah diketahui bahwa berputarnya roda organisasi tergantung sejauh mana dinamika Sumber Daya Manusia yang menjalankan organisasi itu. Berbicara tentang Sumber Daya Manusia berikut dinamikanya senantiasa tidak akan lepas dengan membicarakan apa yang disebut dengan kinerja. Bisa diilustrasikan seperti “ Sumber Daya Manusia merupakan hardware, sedangkan Kinerja merupakan software dalam sebuah organisasi.

Manajer atau pimpinan memiliki andil yang sangat besar terhadap kinerja organisasi dan kinerja personil di tubuh organisasi. Dalam menjalankan kepemimpinan, tingkat kualitas pimpinan bisa di jabarkan sebagai berikut : tidak memuaskan, yaitu gagal dalam menunjukkan kualitas yang dapat diterima; di bawah rata - rata yaitu tidak mencapai rata - rata yang lazim, rata rata yaitu menunjukkan kualitas rata rata; memuaskan yaitu kemampuan visioner dan kuat luar biasa yaitu unggul dalam inspirasi ( Anwar Prabu Mangkunegara, 2014: 35 ).

Pencirian bagi seorang pimpinan dalam memimpin pada suatu situasi, sangat penting untuk impression management atau memunculkan kesannya terhadap yang dipimpin lalu yang dipimpin mengapresiasi, atau tidak sama sekali, sesungguhnya

peristiwa tersebut memasuki wilayah kecenderungan dramaturgi. Dari pemahaman ini sebagai babak awal untuk memahami korelasi Dramaturgi terhadap kinerja.

Peresentuhan hal hal yang sifatnya banyak luput dari analisis adalah korelasi kinerja dengan hal hal situasional antara pimpinan dengan bawahan dalam tekstual hubungan kerja namun menjadi style kinerja kontekstual manakala ditemukan hal hal unik yang mempengaruhinya. Fenomena inilah sebagai prolog tentang adanya impression management dari pimpinan untuk memotivasi,mengarahkan, deccesion, dan berbagai macam role kepemimpinan yang dijalankan. Impression management merupakan identifakasi seni untuk membangun situasi yang diharapkan, dari pemahaman inilah berawal bangunan kerangka teoritis dramaturgis ada dalam kehidupan sehari hari, hadir dalam sebuah organisasi yang mempengaruhi kinerja.

Goffman selaku pencetus teori Dramaturgi membuat rumusan tentang Dramaturgi sebatas general conceptional. Pada perkembangan selanjutnya banyak ahli lain punya andil dalam merumuskan. Bentley mengasumsikan dramaturgi bahwa kehidupan merupakan kesuksessan pertunjukan diamana orang duduk dan 
berdiri sebagai aktifvitas, dialog timbal balik, menggerakkan tangan terhadap orang lain : apakah itu rasa cinta, suka atau tidak suka ( dalam Paul Hare,1985 : 7).

Rumusan tentang Dramaturgi secara general holistik merupakan impresion managemen terhadap dua stuasi social yakni pentas belakang ( back stage ), pentas depan ( front stage ) melalui interaksi yang sifatnya situasional kemudian dijabarkan ke bentuk bagaimana variasi - variasi dalam interaksi tersebut dibangun. Adalah Hodgson and Richards menitik beratkan Dramaturgi sebagai suatu kelebihan berdasarkan pengalaman yang diaplikasikan pada interaksi sosial melalui pendapat mereka yaitu : pengalaman Dramaturgi adalah suatu kelebihan dalam pengalaman kehidupan, melaksanakan pengaturan dan seleksi kembali berbagai bentuk dan mengadakan komunikasi di kalangan aktor dengan di iringi kehadiran audien di suatu tempat. Komunikasi tersebut menghasilkan berbagai situasi ; situasi mental, situasi emosional, penglihatan, pendengaran, dan unsur keindahan ( A. Paul Hare, 1985 : 46 ).

Beranjak dari paparan di atas sampailah ke rumusan operasional Dramaturgi, adalah tentang bagaimana wujud interaksi sosial pada pentas belakang dan pentas depan. Dengan merujuk ke pemikiran Hodgson dan Richard : pada prinsipnya merupakan suasana komunikasi/interaksi dengan segala corak dinamika dan hal hal yang menyertainya antara aktor dengan audien. Dalam hal ini aktor merupakan konotasi terhadap pimpinan, sedangkan audien adalah konotasi terhadap yang dipimpin (karyawan).

Faktor kepemimpinan pun merupakan faktor yang berpengaruh terhadap kinerja. Jadi bila memahami kinerja sacara holistik sama halnya menganalisis multy variabel yang berkaitan dengan kinerja itu sendiri. Dan kepemimpinan yang diidentifikasi memiliki analogi yang kuat dengan Dramaturgi, yaitu kepemimpinan yang ber orientasi sudut pandang sifat.

Persfektif teori sifat untuk menjelaskan kepemimpinan, mengaitkan karakteristik - karakteristik seperti kepribadian, emosional, fisik, intellektual dan karakteristik lainnya dari pimpinan yang berhasil di masa lampau ( Danang Sunyoto,2013: 25 ).

Pada lembaga perguruan tinggi memiliki budaya organisasi yang khas, namun tetap tidak bisa lepas dari pembahasan kepemimpinan dan perilaku bila ingin mengkaji kinerja sumber daya manusia nya. Adalah sudah cukup banayak referensi yang mengulas tentang kepemimpinan. Namun sebaliknya, masih minim kajian - kajian tentang perilaku situasional. Sungguhpun para ahli berpendapat dalam berbagai ulasan bahwa perilaku menduduki posisi penting, termasuk juga pada perguruan tinggi.

Keberhasilan di era globalisasi menurut Soeherdro ( dalam Arwildayanto, 2013: 145 ) ditentukan oleh produktivitas, efisien dalam bekerja. Modal penggeraknya SDM berkualitas yang di hasilkan dari perguruan tinggi terbaik. Keberhasilan perguruan tinggi dala menghasilkan SDM berkualitas dapat dilakukan dosennya dengan memiliki pengetahuan, keterampilan, sikap, tingkah laku baik, handal, professional guna mendorong terlaksananya fungsi tridharma perguruan tinggi. Konsekuensinya perguruan tinggi dituntut untuk membangun budaya Akademik dan etika keilmuan sehingga memberi pencerahan pada masyarakat kampus. Untuk mencapai itu dosen perlu dibina melalui pengembangan budaya kerja sebagai satu peluang untuk membangun pengembangan sumber 
daya manusia melalui penanaman nilai, keyakinan, norma, pandangan, kebiasaan, dan kepemimpinan untuk melakukan perubahan sikap dan perilaku yang diharapkan mampu menyesuaikan diri dengan tantangan yang sedang berjalan dan akan datang. ( Triguna dalam Arwildayanto, 2013: 143 ).

Budaya kerja dosen akan menjadi kenyataan bila diadakan pembinaan oleh pimpinan termasuk pembinaan job behavior. Sebab budaya kerja dosen bukan hanya mengulas tentang pengembangan knowledge dan skill tetapi lebih dari itu yang mengarah pada kemampuan pengendalian diri, kecerdasan sosial, serta dalam dirinya tertanam sebagai sosok yang dijadikan contoh, baik di dalam kampus mampu di luar kampus.

Alasan dan arti penting mengelola SDM, ulasan tentang perwujudan potensi SDM, kepemimpinan, kinerja dalam menghadapi era globalisasi bagi perguruan tinggi seperti yang telah dijabarkan merupakan masalah yang sama dengan yang dihadapi perguruan tinggi yang menjadi objek penelitian ini. Adapun objek penelitian adalah Akademi Manajaemen dan Informasi Komputer Citra Buana Indonesia yang berlokasi di Kota Sukabumi Propinsi Jawa Barat. Nama Perguruan Tinggi ini di sebut dengan AMIK CBI.

Berbagai fenomena yang terjadi pada Akademi Manajemen Informatika dan Komputer Citra Buana Indonesia Kota Sukabumi dalam konteks kinerja sebagai unsur yang dipengaruhi oleh Dramaturgi dan Kepemimpinan . Pengaruh kepemimpinan terhadp kinerja sudah banyak dibahas, namun memperbandingkan kekuatan pengaruh Dramaturgi dengan kepemimpinan terhadap kinerja menjadikan penelitian ini punya ciri sendiri.

\section{METODE PENELITIAN}

\section{A. Pertanyaan Penelitian dan Hipotesis}

\section{Pertanyaan Penelitian :}

- Sejauh mana mana pengaruh Dramaturgi terhadap Kinerja karyawan AMIK CBI ?

- Sejauh mana pengaruh Kepemimpinan terhadap Kinerja karyawan AMIK CBI?

- Sejauh mana pengaruh Dramaturgi dan Kepemimpinan sekaligus terhadap Kinerja karyawan AMIK CBI ?

- Sejauh mana pengaruh Dramaturgi terhadap Kinerja karyawan melebihi Pengaruh kepemimpinan terhadap Kinerja karyawan?

\section{Hipotesis}

- Pengaruh Dramaturgi terhadap kinerja karyawan positif dan signifikan ( X1 )

- Pengaruh Kepemimpinan terhadap kineja karyawan positif dan siginifikan (X2)

- Pengaruh Dramaturgi dan Kepemimpinan terhadap kinerja karyawan positif dan signifikan $(\mathrm{X} 1+\mathrm{X} 2)$

- Pengaruh Dramaturgi terhadap kinerja karyawan lebih tinggi daripada pengaruh kepemimpinan terhadp kinerja karyawan ( X1:X2)

\section{B. Desain Penelitian}

Desain penelitian adalah explanasi yakni menguji hubungan antar variabel pada hipotesis : apakah antar variabel berhubungan atau berpengaruh terhadap variabel lain. Selain itu format eksplanasi juga juga mengarah kepada generalisasi sample terhadap populasi. Penerapan desain eksplanasi berbasis kuantitatif, bertujuan untuk mengetahui pengaruh Dramaturgi ( $\mathrm{X} 1$ ) terhadap kinerja ( $\mathrm{Y}$ ) dan komperatif nya 
terhadap kepemimpinan ( X2), Pengaruh Kepemimpinan ( X2 ) terhadap kinerja ( Y ). Pengaruh X1 dan X2 sekaligus terhadap Y.

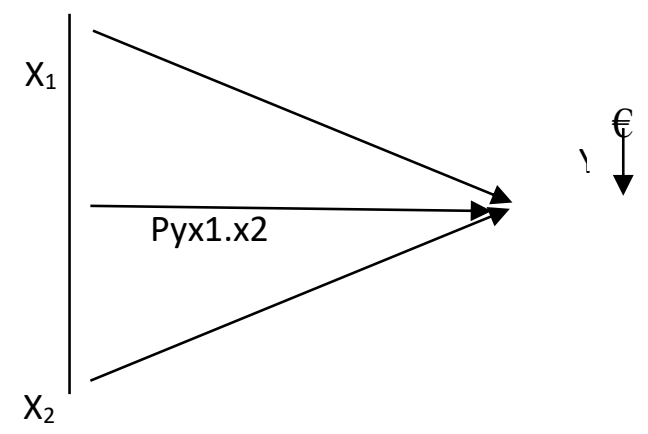

Keterangan

$\mathrm{X}_{1} \quad=$ Dramaturgi

$\mathrm{X}_{2} \quad=$ Kepemimpinan

$\mathrm{Y} \quad=$ kinerja

$€ \quad=$ Variabel lain yang ikut

mempengaruhi $\mathrm{Y}$

C. Distribusi sample menurut srtata berdasarkan stratified random sampling

- Jumlah populasi berdasarkan masing masing strata : Karyawan tetap $=12$ orang, Rumusan Distribusi : Populasi setiap Strata. $\times \frac{n}{N}=12 \times \frac{50}{88}=$ Jumlah sample : 7 orang

- Jumlah populasi berdasarkan masing masing strata : Dosen tetap $=14$ orang, Rumusan Distribusi : Populasi Setiap Strata $\times \frac{n}{N}=14 \times \frac{50}{88}=$ Jumlah sample : 8 orang

- Jumlah populasi berdasarkan masing masing strata : Dosen tidak tetap $=62$ orang, Rumusan Distribusi : Populasi Setiap Strata $\times \frac{n}{N}=65 \times \frac{50}{88}=$ Jumlah sample : 35 orang

Jadi dari $\mathrm{N}=88$, maka $\mathrm{n}=50$.

\section{Teknik Pengumpulan Data}

Teknik pengumpulan data dilakukan dengan observasi untuk mengetahui karakteristik, struktur keorganisasisan dan data kelola kepemimpinan. Lalu dilakukan pula teknik pengumpulan data melalui questioner terhadap 50 orang responden. Adapun teknik pengumpulan data dengan wawancara dilakukan untuk mengidentifikasi fenomena - fenomena yang tidak tercakup pada observasi dan questioner.

\section{HASIL PENELITIAN}

\section{A. Dimensi Dramaturgi :}

- Back stage ( panggung belakang) :

1. Komunikasi atasan melalui naskah / tulisan terhadap karyawan, 2. Komuikasi atasan dengan lisan terhadap karyawan, 3. Kekuatan gestural atasan terhadap karyawan, 4. Kekuatan perangkat peran atasan terhadap karyawan.

- Front stage ( panggung depan ) :

Atasan tampil saat karyawan mengerjakan pekerjaaan berat, 2. Atasan tampil saat karyawan sedang terleha leha / santai, 3. Atasan tampil dengan pakaian dinas kantor tehadap karyawan, 4. Atasan tampil sacara bersahaja terhadap karyawan, 5. Atasan tampil beromunikasi dengan lembut terhadap karyawan, 6. Atasan tampil terhadap karyawan dengan menekankan faktor - faktor target tertentu, 7. Atasan tampil terhadap karyawan berdasarkan indikator waktu, 8. Atasan tampil terhadap karyawan pada saat karyawan memulai pekerjaan.

\section{B. Dimensi Kepemimpinan :}

1.Sejarah oranisasi, 2.Umur pemimpinan, 3.Pengalaman pimpinan, 4.Lingkungan, 5.Persyarat kerja, 6.Suasana psikologis, 7.Sifat pekerjaan, 8.Ukuran organisasi, 9.Tingkat kerjasama, 10.Harapan karyarwan, 
11.Kepribadian karyawan, 12.Indicator waktu dalam mengambil keputusan

\section{Dimensi Kinerja :}

1.Hasil kerja, 2.Keterampilan kerja, 3.Pengetahuan jabatan, 4.Pengambilan keputsan, 5.Kepemimpinan, 6.Kerja sama, 7.Tanggung jawab, 8.Disiplin, 9.Inisiatif 10.Komunikasi, 11.Melayani, 12.Sikap

\section{Uji T Untuk Hipotesis :}

koefisien regresi parsal - Dramaturgi coefficents

\begin{tabular}{|l|l|l|l|l|l|}
\hline $\begin{array}{l}\text { Mod } \\
\text { el }\end{array}$ & \multicolumn{2}{|l|}{$\begin{array}{l}\text { Unstandard } \\
\text { ized } \\
\text { coefficients }\end{array}$} & $\begin{array}{l}\text { Standa } \\
\text { rdized } \\
\text { coeffi } \\
\text { cients }\end{array}$ & T & $\begin{array}{l}\text { S } \\
\text { ig } \\
\cdot\end{array}$ \\
\cline { 2 - 4 } & B & $\begin{array}{l}\text { Std. } \\
\text { error }\end{array}$ & Beta & & \\
\hline (con & 18, & 10,30 & 454 & 1, & 0 \\
stant & 849 & 6,173 & & 82 & 7 \\
) &, & & & 9 & 4 \\
X1 & 609 & & & 3, & 0 \\
& & & & 82 & 0 \\
\end{tabular}

a.Dependen Variabel : Y

Dari perhitungan SPSS, $\mathrm{t}$ hitung yang diperoleh adalah sebesar 3,528 sedangkan

$\mathrm{t}$ tabel dengan derajat bebas 48 pada $\alpha$ $(0,05)$ adalah sebesar 1,96. Dengan demikian, $\quad \mathrm{t}_{\text {hitung }}(3,528)>\mathrm{t}$ tabel ( 1,96), sehingga jelas.

Ho ditolak dan $\mathrm{H} 1$ diterima. Kondisi tersebut menunjukkan bahwa Dramaturgi berpengaruh positif dan signifikan terhadap kinerja, dan besarnya pengaruh adalah 0,206 atau 20,6\%.

\begin{tabular}{|l|l|l|l|l|}
\multicolumn{1}{|c|}{ Model summary } \\
\begin{tabular}{|l} 
Mod \\
el
\end{tabular} & $\mathrm{R}$ & $\begin{array}{l}\mathrm{R} \\
\text { squar } \\
\text { e }\end{array}$ & $\begin{array}{l}\text { Adjust } \\
\text { ed R } \\
\text { square }\end{array}$ & \begin{tabular}{l} 
Std. \\
$\begin{array}{l}\text { Error } \\
\text { of the } \\
\text { estima } \\
\text { te }\end{array}$ \\
\hline
\end{tabular}
\end{tabular}

\begin{tabular}{|l|l|l|l|l|}
\hline 1 & $\begin{array}{l}454 \\
\mathrm{a}\end{array}$ & 206 & 186 & $\begin{array}{l}7,7771 \\
9\end{array}$ \\
\hline
\end{tabular}

a.predicators : ( constant), X2

\section{E. Uji t hipotesis}

Koenfisien pengujian persial kepemimpinan coefficents

\begin{tabular}{|c|c|c|c|c|c|}
\hline \multirow[t]{2}{*}{$\begin{array}{l}\text { Mod } \\
\text { el }\end{array}$} & \multicolumn{2}{|c|}{$\begin{array}{l}\text { Unstandard } \\
\text { ized } \\
\text { coefficients }\end{array}$} & $\begin{array}{l}\text { Standa } \\
\text { rdized } \\
\text { coeffi }\end{array}$ & \multirow[t]{2}{*}{$\mathrm{T}$} & \multirow[t]{2}{*}{$\begin{array}{l}\text { S } \\
\text { ig }\end{array}$} \\
\hline & B & $\begin{array}{l}\text { Std. } \\
\text { error }\end{array}$ & Beta & & \\
\hline $\begin{array}{l}\text { (con } \\
\text { stant } \\
\text { X2 } \\
\text { X2 }\end{array}$ & $\begin{array}{l}34, \\
859 \\
311\end{array}$ & $\begin{array}{l}15,58 \\
7,240\end{array}$ & 184 & $\begin{array}{l}1, \\
23 \\
6 \\
1, \\
29 \\
6\end{array}$ & $\begin{array}{l}0 \\
3 \\
0 \\
2 \\
0 \\
1\end{array}$ \\
\hline
\end{tabular}

Dari perhitungan SPSS, t hitung yang diperoleh terhadap b1 adalah sebesar 1,296 sedangkan t tabel denga derajat bebas 49 pada $\alpha(0,05)$ adalah sebesar 1,96. Dengan demikian, t hitung 1,296< $\mathrm{t}$ tabel $(1,96)$, sehigga jelas Ho diterima dan H1 ditolak. Kondisi tersebut menunjukkan bahwa variable bebas X1 berupa kepemimpinan berpengaruh positif namun tidak signifikan terhadap variable terikat $\mathrm{Y}$ berupa kinerja pada akademi manajemen informatika dan computer citra uana Indonesia kota sukabumi, sedangkan besarnya pengaruh adalah sebesar 0,034 atau 3,4 \% ( lihat tabel 4-11: model summary seperti disajikan bawah ini :

Model summary
\begin{tabular}{|l|l|l|l|l|}
\hline $\begin{array}{l}\text { Mod } \\
\text { el }\end{array}$ & R & $\begin{array}{l}\text { R } \\
\text { squar } \\
\text { e }\end{array}$ & $\begin{array}{l}\text { Adjust } \\
\text { ed R } \\
\text { square }\end{array}$ & $\begin{array}{l}\text { Std. } \\
\text { Error } \\
\text { of the } \\
\text { estima } \\
\text { te }\end{array}$ \\
\hline 1 & $\begin{array}{l}184 \\
\text { a }\end{array}$ & 034 & 014 & $\begin{array}{l}8,5785 \\
3\end{array}$ \\
\hline
\end{tabular}


a.predicators : ( constant), X2

\section{F. Uji F untuk Hipotesis}

Hipotesis yang di ajukan adalah : kepemimpinan dan Dramaturgi secara bersama - sama berpengaruh signifikan terhadap kinerja, satu dengan rumusan matematis dapat diuraikan sebagai berikut :

- $\mathrm{H}_{0}$ : bl = b2 = 0 : Dramaturgi dan Kepemimpinan secara Bersama - sama tidak berpengaruh signifikan terhadap kinerja.

- $\mathrm{H}_{1}$ : salah satu atau keduanya bl \# 0 : Dramaturgi dan kepemimpinan secara besama - sama berpengaruh signifikan terhadap kinerja. Jika nilai $\mathrm{F}$ hitung $>\mathrm{F}$ tabel maka Ho ditolak dan $\mathrm{H} 1$ diterima hasil perhitungan kedua variabel bersam - sama sebagi berikut:

\section{ANOVA}

a.dependent variabel : $\mathrm{Y}$

b.predicators : ( constant ), X1,X2

Dari hasil pengolahan dat penelitian dengan bantuan perhitungan computer program SPSS versi 20 diperoleh nilai $F$ hitung sebesar 6,522 sedangkan besarnya $\mathrm{F}$ tabel dengan derajat bebas (df) 2 dan 48 pada $\alpha(0,05)$ sebesar 3,17. Dengan demikian niai $\mathrm{F}$ hitung ( 6,522) $>\mathrm{F}$ tabel ( 3,17), sehingga Ho ditolak dan $\mathrm{H} 1$ diterima, dengan demikian maka dapat disimpulkan bahwa kepemimpinan dan Dramaturgi secara berama - sama memiliki pengaruh yang signifikan terhadap kinerja karyawan pada Akadem Manajemen Informatika Kompoter Citra Buana Indonesia sukabumi. Adapun besarnya pengaruh dapat dilihat pada tabel summary berikut yaitu sebesar 0,217 atau $21,7 \%$.

\begin{tabular}{|l|l|l|l|l|}
\hline $\begin{array}{l}\text { Mod } \\
\text { el }\end{array}$ & $\mathrm{R}$ & $\begin{array}{l}\mathrm{R} \\
\text { squar } \\
\mathrm{e}\end{array}$ & $\begin{array}{l}\text { Adjust } \\
\text { ed R } \\
\text { square }\end{array}$ & $\begin{array}{l}\text { Std. } \\
\text { Error } \\
\text { of the } \\
\text { estima } \\
\text { te }\end{array}$ \\
\hline
\end{tabular}

\begin{tabular}{|l|l|l|l|l|}
\hline 1 & 46 & 217 & 184 & $\begin{array}{l}7,8030 \\
6\end{array}$ \\
\hline
\end{tabular}

\section{G. Koenfiien Daterminasi}

Koenfisien daterminasi dipergunakan untuk mengetahui tingkat keagamaan variabel terikat $\mathrm{Y}$ ( kinerja ) yang di sebabkan leh pada perbedaan variabel bebas 1 ( kepemimpinan ) dan variabel bebas 2 ( Dramaturgi ). Dengan bantuan pengolahan computer tehadap data penelitian berdasarkan perhitungan SPPS versi 20 diperoleh nilai R2 ( $\mathrm{R}$ square ) sebesar 0,217 atau 21,7\%, artinya besarnya pengaruh Dramaturgi (X1) Kepemimpinan ( X2 ) secara Bersama - sama terhadap kinerja ( Y ) sebesar $21,7 \%$, sedangkan sisa nya dipengaruhi oleh factor lan sebesar $78,3 \%$

\section{H. Persamaan regresi berganda}

Persamaan regresi berganda merupakan

\begin{tabular}{|c|c|c|c|c|c|}
\hline Model & $\begin{array}{l}\text { Sum } \\
\text { of } \\
\text { squar } \\
\text { es }\end{array}$ & $\begin{array}{l}\mathrm{d} \\
\mathrm{f}\end{array}$ & $\begin{array}{l}\text { Mea } \\
\mathrm{n} \\
\text { squa } \\
\text { re }\end{array}$ & $\mathrm{F}$ & $\begin{array}{l}\mathrm{Si} \\
\text { g. }\end{array}$ \\
\hline $\begin{array}{l}\text { Regres } \\
\text { sion } \\
\text { Residu } \\
\text { al } \\
\text { Total }\end{array}$ & $\begin{array}{l}749,2 \\
79 \\
2861, \\
721 \\
3656, \\
000\end{array}$ & $\begin{array}{l}2 \\
4 \\
7 \\
4 \\
9\end{array}$ & $\begin{array}{l}397, \\
239 \\
60,8 \\
88\end{array}$ & $\begin{array}{l}6,5 \\
22\end{array}$ & $\begin{array}{l}00 \\
3 b\end{array}$ \\
\hline
\end{tabular}

model persamaan regresi untuk melihat pengaruh Dramaturgi ( X1 ) dan Kepemimpinan secara bersama - sama terhadap kinerja ( $\mathrm{Y}$ ). Drai hasil pengolahan computer berdasarkan perhitungan SPS versi 20 di peroleh seperti pada tabel berikut :

coefficents

\begin{tabular}{|c|c|c|c|c|c|}
\hline Model & \multicolumn{2}{|c|}{$\begin{array}{c}\text { Unstandardi } \\
\text { zed } \\
\text { coefficients }\end{array}$} & $\begin{array}{c}\text { Standardi } \\
\text { zed } \\
\text { coefficien } \\
\text { ts }\end{array}$ & T & $\begin{array}{c}\mathrm{Si} \\
\mathrm{g} .\end{array}$ \\
\cline { 2 - 4 } & $\mathrm{B}$ & $\begin{array}{c}\text { Std. } \\
\text { error }\end{array}$ & Beta & & \\
\hline
\end{tabular}




\begin{tabular}{|l|l|l|l|l|l|}
\hline (consta & 8,49 & 16,2 & & 523 & 60 \\
nt) & 3 & 52 & 108 & 826 & 4 \\
X1 & 183 & 222 & 432 & 3,31 & 41 \\
X2 & 584 & 176 & & 9 & 3 \\
& & & & & 00 \\
& & & & & 2 \\
\hline
\end{tabular}

Berdasarkan perhitungan tersebut diperoleh persamaan :

$\mathrm{Y}=8,493+0,183 \mathrm{X} 1+0,548 \mathrm{X} 2$

Persamaan ini berarti bahwa :

1. Setiap kenaikkan 1 skor variabel Dramaturgi ( X1 ) berpengaruh terhadap peningkatan variabel kinerja ( $\mathrm{Y}$ ) sebesar 0,183 dengan asumsi variabel Kepemipinan ( X2)

\section{PEMBAHASAN}

\section{A. Pengaruh Dramaturgi Terhadap Kinerja Karyawan AMIK CBI}

Dari hasil penelitian menunjukkan pengaruh Dramaturgi terhadap kinerja karyawan AMIK CBI positif dan signifikan, sebesar 20,6\%, maknanya adalah impression management lebih tinggi kesan dan dampaknya daripada action of leadership terhadap kinerja karyawan tetap, deosen tetap, dan dosen tidak tetap.

Makna defenitif bisa dijabarkan bahwa bagi karyawan tetap, dosen tetap, dan dosen tidak tetap lebih menerima, membekas dengan metode peniruan dan penauladanan melalui performance, gaya (manner) yang di kategorikan sebagai personel front, mengkondisikan ( setting ) yang merupakan konteks Dramaturgi dari pada konteks kepemimpinan berdasarkan teori situsional. Perbandingan kedua pengaruh tersebut terealisasi dalam bentuk kinerja karyawan AMIK CBI.

Apa yang disebut Cooley tentang teori Self Glass sangat relavan dan mendukung terhadap mengapa seseorang ingin memperbaiki diri melalui bagaimana cara memandang orang lain. Sebagaimana halnya anak kecil dalam bertindak dan berperilaku berdasarkan apa yang dilihat, didengar, dikondisikan orang tua nya. Adakalanya kenyataan tersebut lebih kuat pengaruhnya daripada perintah verbal, doktrin, sanksi.

Sebenarnya teori kepemimpinan sudah sampai kepada pemahaman dan analisis tentang peniruan dan peneladanan melalui predikat sifat / karakter pimpinan yang disebut dengan teori sifat kepemimpinan. Namun tidak satupun dimensi sifat dalam teori tersebut terbukti secara permanen sehingga menjadikan lemah tingkat keilmiahannya. Sebagi contoh, adalah sulit membuktikan pimpinan yang permanen dalam keberanian, kejujuran, keyakinan diri, (Self Confidence). Jadi jelaslah bahwa kelemahan teori sifat dalam kepemimpinan telah mengabaikan hal - hal yang sifatnya situasional.

\section{B. Pengaruh Terhadap AMIK CBI}

Berdasarkan perhitungan statistik dengan menggunakan IBM SPSS for windows 21 maka di peroleh hasil bahwa terdapat pengaruh positif namun tidak signifikan kepemimpinan terhadap kinerja karyawan. Besarnya pengaruh tersebut adalah 3,4\%. Menurut standar kategori Guilford (Guilford, 165 : 145) termasuk kedalam kategori sangat rendah atau hampir tidak ada pengaruh.

Hasil penelitian menunjukkan bahwa kepemimpinan pada AMIK CBI tidak berpengaruh langsung terhadap kinerja karyawan, tetapi mungkin berpengaruh langsung terhadap motivasi karyawan, baru setelah itu motivasi karyawan yang berpengaruh terhadap kinerja karyawan. Hal ini sesuai dengan pendapat beberapa ahli manajemen yang menyebutkan bahwa kepemimpinan memiliki peranan besar terhadap motivasi karyawan (Kartono, 2005 : 
179). Sebagimana menurut pendapat Mangkunegara, bahwa motivasi karyawan memiliki peran langsung terhadap kinerja karyawan (Mangkunegara : 2007). Namun tetap saja keberhasilan organisasi dalam mencapai tujuan yang ingin diraih bergantung pada kepemimpinannya, yaitu apakah kepemimpinan tersebut mampu mengoptimalkan sumber daya lain seperti sumber daya alam, sarana, dana, kemampuan tiknis, kemampuan sosial, dan kemampuan konseptual dalam proses manajemen.

\section{Kinerja Karyawan AMIK CBI}

Dua belas dimensi kinerja yang diteliti merupakan dimensi yang signifikan untuk disetujui oleh responden. Sebanyak 90\% responden menjawab sangat setuju dan setuju terhadap dimensi kinerja tersebut.

\section{Pengaruh Dramaturgi dan Kepemimpinan Secara Simultan Terhadap kinerja Karyawan AMIK CBI}

Merupakan analisis yang penting akumulasi atas penggabungan pengaruh Dramaturgi dengan Kepemimpinan terhadap kinerja karyawan AMIK CBI. Pengaruh kepemimpinan dan Dramaturgi secara simultan terhadap kinerja karyawan AMIK CBI adalah positif dan signifikan, yaitu sebesar 21,7 $\%$.

\section{E. Ada Pengaruh Faktor lain (epsilon)}

Ada pengaruh faktor lain (epsilon) terhadap kinerja karyawan AMIK CBI sebesar 78,3\%, selain pengaruh Dramaturgi dan Kepemimpinan.

\section{F. Kekuatan Pengaruh Dramaturgi Melebihi Kepemimpinan}

Dari hasil olahan data menunjukkan pengaruh Dramaturgi lebih kuat atau lebih tinggi mempengaruhi kinerja karyawan dibanding pengaruh kepemimpinan terhadap kinerja karyawan. Untuk memperjelas mengapa teori Dramaturgi lebih tinggi pengaruhnya daripada kepemimpinan berdasarkan persfektif situasioal, secara sederhana dapat dijawab bahwa dalam teori Dramaturgi, si aktor dan sutradara /pimpinan tidak pernah dibakukan predikat sifat terhadapnya. Jadi dalam teori Dramaturgi tidak ada sebutan pimpinan rajin, berani, dan predikat lainnya. Yang terpentig dalam Dramaturgi adalah bagaimana keberadaan yang berulang - ulang /pembiasaan di pentas belakang dan di pentas depan, mengkondisikan situasi dan keadaan serta perlengkapan / fasilitas ( setting ) yang dibutuhkan untuk mendukung personal front ( performance dan manner ) untuk mencapai tujuan. yang diinginkan terhadap audien. Bila dianalogikan terhadap Dramaturgi atas paparan tersebut, identifikasi tujuan adalah kinerja, sedangkan identifikasi audien adalah karyawan AMIK CBI / (responden). Adapun yang diidentifikasi sebagai sutradara adalah pimpinan yang dalam hal ini adalah direktur dan ketua $\mathrm{BPH}$.

\section{KESIMPULAN}

1. Pengaruh Darmaturgi terhadap kinerja karyawan AMIK CBI adalah positif dan signifikan, yaitu sebesar $20,6 \%$.

2. Pengaruh kepemimpinan terhadap kinerja karyawan AMIK CBI adalah positif namun tidak signifikan, yaitu sebesar 3,4\%.

3. Pengaruh kepemimpinan dan Dramaturgi secara simultan terhadap kinerja karyawan AMIK CBI adalah positif dan signifikan, yaitu sebesar $21,7 \%$.

4. Sedangkan pengaruh factor lain ( epsilon ) sebesar 78,3\%. 
5. Pengaruh Dramaturgi terhadap kinerja karyawa lebih besar di banding pengaruh kepemimpinan terhadap kinerja karyawan yaitu $21,7 \%$ berbanding $3,4 \%$.

\section{DAFTAR PUSAKA}

Arwildayanto, Manajemen Sumber Daya Manusia Perguruan Tinggi Pendekatan Budaya Kerja Dosen Professional, CV. Alfabeta, Bandung, 2013

B. Horton, Pau, Chester L.Hunt, Sosiologi Jilid I, Erlanga, Jakarta 1987

Bersheid, Walster, Interperonal Attaraction, Wesley Publishing Company, Philipines, 1969

Contents Of Dramaturgi From Wikipedia.org, Copy Date 15 Desember 2014

Hamzah, A.adjib, Pengantar Bermain Drama, CV. Rosda, Bandung, 1985

Hare, A.paul, Social Interaction as Drama, Baverly Hills, California, 1985

Indrajaya, Ibrahim Adam, Teori Perilaku dan Budaya Organisasi. PT. Refika Aditama, Bandung, 2010

J.leavt, Harol, Psiologi Manajemen, Erlangga, Jakarta, 1986

Jehan, W.George, Teknik Berbicara yang Meyakinkan dan Efektif, Gunung Jati, Jakarta, 1976

Mulyadi, Muhammad, Penelitian Kwantitatif dan Kwalitatif, Serta Praktik Kombinasinya dalam Penelitian Publica Institute, Jakarta, 2012

Sulaeman, Stlanti, Pengaruh Motifasi dan Disiplin Kerja Terhadap Kinerja Pegawai Pada Sekertariat Kota Sukabumi ( skripsi ), STIAMI, Jakarta, 2015
Sungota, Danang, Teori Kuistioner dan Proses Analisis Data Perilaku Orgaisasional, CAPS, Jakarta, 2013

Thoha, Miftah, Perilaku Organisasi Konsep Dasar dan Aplikasi, CV. Rajawali, Jakarta,1983

Tim, Kamus Istilah Sosiologo, Pusat Pembinaan dan Pengembangan Bahasa Dekdipbud, Jakarta 1984.

Wart, Peter, Psikologis Perubahan dan Perundingan Kolektif, PT. Pustaka Binaman Pressink, Jakarta, 1984

Wibowo Manajemen Kinerja, Rajawali Pers, PT. Raja Grafindo Persada, Jakarta, 2012

Statuta AMIK CBI, Sukabumi, 2014 